University of Nebraska - Lincoln

DigitalCommons@University of Nebraska - Lincoln

\title{
Effects of surface run-off on the transport of agricultural chemicals to ground water in a sandplain setting
}

Geoffrey N. Delin

US Geological Survey

Matthew K. Landon

US Geological Survey

Follow this and additional works at: https://digitalcommons.unl.edu/usgsstaffpub

Part of the Earth Sciences Commons

Delin, Geoffrey N. and Landon, Matthew K., "Effects of surface run-off on the transport of agricultural chemicals to ground water in a sandplain setting" (2002). USGS Staff -- Published Research. 226.

https://digitalcommons.unl.edu/usgsstaffpub/226

This Article is brought to you for free and open access by the US Geological Survey at DigitalCommons@University of Nebraska - Lincoln. It has been accepted for inclusion in USGS Staff -- Published Research by an authorized administrator of DigitalCommons@University of Nebraska - Lincoln. 


\title{
Effects of surface run-off on the transport of agricultural chemicals to ground water in a sandplain setting
}

\author{
Geoffrey N. Delin ${ }^{\mathrm{a}, *}$, Matthew K. Landon ${ }^{\mathrm{b}}$ \\ ${ }^{\mathrm{a}}$ US Geological Survey, 2280 Woodale Drive, Mounds View, MN 55112, USA \\ ${ }^{\mathrm{b}}$ US Geological Survey, 406 Federal Bldg. 100 Centennial Mall No. Lincoln, NE 68508, USA
}

Received 3 August 2001; accepted 29 January 2002

\begin{abstract}
An experiment was conducted at a depressional (lowland) and an upland site in sandy soils to evaluate the effects of surface run-off on the transport of agricultural chemicals to ground water. Approximately $16.5 \mathrm{~cm}$ of water was applied to both sites during the experiment, representing a natural precipitation event with a recurrence interval of approximately 100 years. Run-off was quantified at the lowland site and was not detected at the upland site during the experiment. Run-off of water to the lowland site was the most important factor affecting differences in the concentrations and fluxes of the agricultural chemicals between the two sites. Run-off of water to the lowland site appears to have played a dual role by diluting chemical concentrations in the unsaturated zone as well as increasing the concentrations at the water table, compared to the upland site. Concentrations of chloride, nitrate and atrazine plus metabolites were noticeably greater at the water table than in the unsaturated zone at both sites. The estimated mass flux of chloride and nitrate to the water table during the test were 5-2 times greater, respectively, at the lowland site compared to the upland site, whereas the flux of sulfate and atrazine plus metabolites was slightly greater at the upland site. Results indicate that matrix flow of water and chemicals was the primary process causing the observed differences between the two sites. Results of the experiment illustrate the effects of heterogeneity and the complexity of evaluating chemical transport through the unsaturated zone. (c) Published by Elsevier Science B.V.
\end{abstract}

Keywords: Focused recharge; Nitrate nitrogen; Atrazine; Run-off

\section{Introduction}

In agricultural landscapes, topography plays an important role in the transport of chemicals to ground water. Because recharge is greatest, or focused, beneath depressions in the land surface (Meyboom, 1966; Lissey, 1971; Miller et al., 1985; Delin et al., 2000), water from surface run-off

\footnotetext{
*Corresponding author. Tel.: +1-763-783-3231; fax: +1763-783-3103.

E-mail address: delin@usgs.gov (G.N. Delin).
}

from the catchment area surrounding a depression likely picks up and carries some of the available agricultural chemicals into the depression. Consequently, the concentrations and fluxes to the water table of chemicals associated with agricultural practices, such as nitrate nitrogen (nitrate), chloride, sulfate, and atrazine, likely are increased in depressions compared to the surrounding uplands.

This paper describes the results of an experiment to evaluate the effects of surface run-off to a depressional area and an upland area on the trans- 


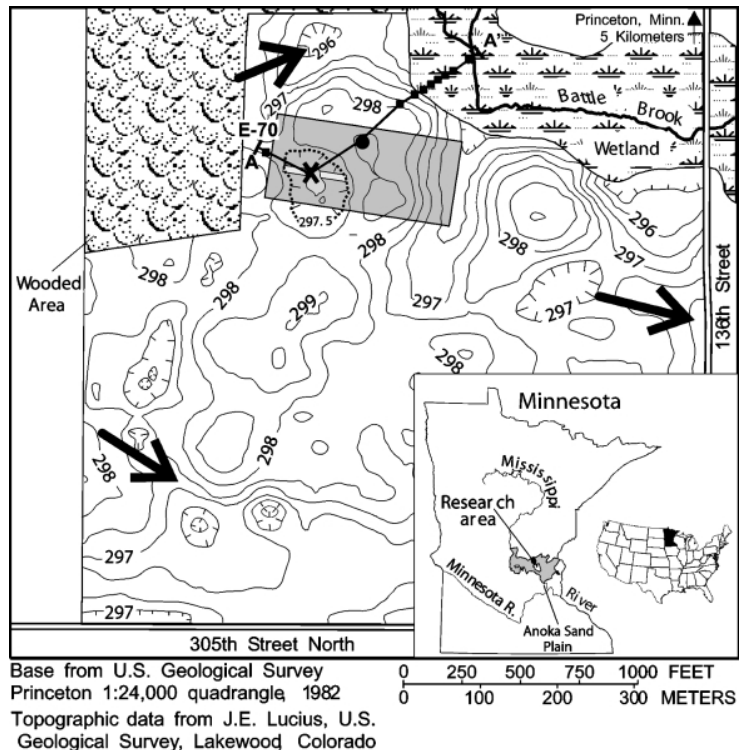

Geological Survey, Lakewood Colorado

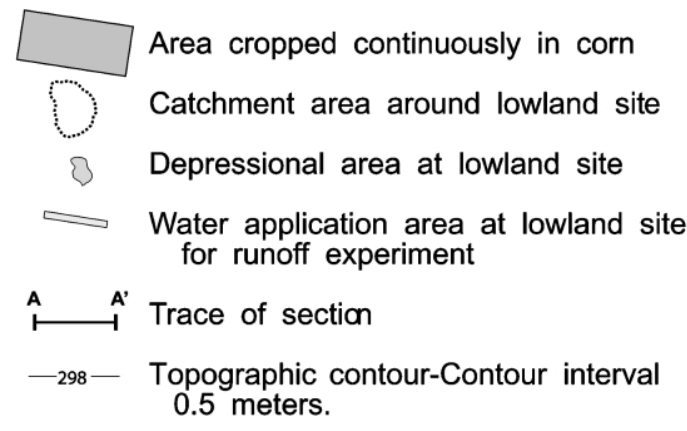

$\rightarrow$ Direction of ground-water flow

- Upland site

X Lowland site

- Observation well

Fig. 1. Topography and layout of the research area near Princeton, Minnesota.

port of agricultural chemicals to ground water. The amount of water used in this experiment (16.5 $\mathrm{cm})$ represents a natural precipitation event with a recurrence interval of 100 years in this region (Huff and Angel, 1992). An evaluation of the effects of such an event provides a useful evaluation of surface run-off in a sand plain setting. For the purpose of this investigation, surface run-off is defined as water that does not immediately infil-

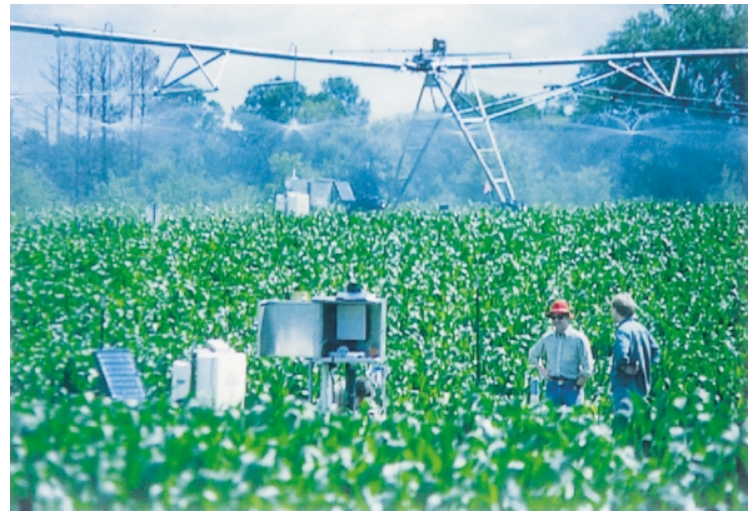

Fig. 2. View of the linear-move irrigation system applying water during a recharge experiment. The lowland site is in the foreground and the upland site in the background underneath the irrigator in this telephoto view. The two sites are approximately $78 \mathrm{~m}$ apart and differ in elevation by $1.4 \mathrm{~m}$. The instrumentation shelters are visible at both sites.

trate the soil but is diverted to an adjacent area of lower elevation. We had two general hypotheses for this experiment: (1) that the difference in recharge between the two sites would be approximately equivalent to run-off to the lowland site; and (2) that the concentrations and fluxes of agricultural chemicals to the water table would be increased at the lowland site compared to the upland site due to run-off. For the purpose of this investigation, recharge is defined as the amount of water from local precipitation that reaches the water table. The research was part of a larger effort to evaluate the effects of transient recharge, topography, and subsurface heterogeneities on the flux of water and agricultural chemicals to the water table (Delin and Landon, 1996; Delin et al., 2000).

\section{Location and description of research area}

The research was done at a topographically high site and a topographically low site within a 2.7-ha field near Princeton, Minnesota in the Anoka sand plain as shown in Fig. 1. The upland and lowland sites were approximately $78 \mathrm{~m}$ apart and differed in land-surface elevation by $1.4 \mathrm{~m}$ as shown in Figs. 1 and 2 (slope of approx. 0.02). The lowland site was selected in part because the slope is steeper than in most of the area (Fig. 1). The 
catchment area around the lowland site covers approximately $8000 \mathrm{~m}^{2}$ and coincides approximately with the 297.5-m contour (Fig. 1). Aquifer porosity in the unsaturated zone and near the water table at both sites is approximately 0.40 (Table 1 ). During the run-off recharge experiment, depth to water at the upland and lowland sites was approximately 4.4 and $2.9 \mathrm{~m}$, respectively, similar to the differences in land-surface elevation.

The 2.7-ha field was cropped in field corn. Fertilizers and the herbicide atrazine were applied to the entire field during 1994. Applications that proved most useful as tracers during the experiment were nitrogen fertilizer (at a rate of 231.2 $\mathrm{kg} / \mathrm{ha}$ ), mainly in the form of urea, and chloride $(46.4 \mathrm{~kg} / \mathrm{ha})$, from potassium-chloride fertilizer. Applications of sulfate, from zinc sulfate, ammonium sulfate, and potassium magnesium sulfate fertilizer $(13.4 \mathrm{~kg} / \mathrm{ha})$ and the herbicide atrazine $(1.7 \mathrm{~kg} / \mathrm{ha})$, also proved useful in evaluating chemical transport through the unsaturated zone. Delin et al. (1994) and Landon et al. (1998) provide detailed descriptions of the farming practices at the site. No additional chemical tracers were applied to the upland and lowland sites prior to the beginning of this experiment.

Topsoil at the upland and lowland sites is 0.4 and $0.8 \mathrm{~m}$ thick, respectively (Delin et al., 1997), with both having less than $1 \%$ organic matter (US Dept. of Agriculture, 1968). The greater thickness of topsoil at the lowland site is presumably due to transport of finer soil particles into the depression by run-off. The glacial outwash deposits to a depth of $2 \mathrm{~m}$ below the land surface are generally similar at both sites, being composed of approximately 95\% sand and 5\% silt and clay (Delin et al., 1996). However, the following important differences in the properties of the unsaturated zone deposits between the two sites have been identified: (1) unsaturated zone deposits are coarser below approximately $1.5 \mathrm{~m}$ in depth at the lowland site (Table 1); (2) organic carbon content is greater at the lowland site (Table 1); (3) unsaturated zone deposits at the upland site are generally more uniform in texture; and (4) fine-grained lamellae occur only in the unsaturated zone at the upland site (Delin et al., 2000).
Average recharge during 1994 was $22 \mathrm{~cm}$ at the upland site and $36 \mathrm{~cm}$ at the lowland site based on hydrograph analysis and an unsaturated-zone water balance (Delin et al., 2000). The increased or focused recharge and more rapid movement of wetting fronts at the lowland site is attributed to three factors: (1) surface run-off of water at the lowland site; (2) silty-sand lamellae that may impede the vertical transport of water at the upland site; and (3) coarser grained sediments at the lowland site at depths greater than approximately $1.5 \mathrm{~m}$ (Delin et al., 2000). The upland and lowland sites are typical of sandy sites in the Midwest corn belt.

\section{Methods of investigation}

The effects of surface run-off on the transport of agricultural chemicals to ground water were evaluated during an experiment during August 29 through September 2, 1994. Approximately 16.5 $\mathrm{cm}$ of water was applied to the upland and lowland sites over a 4-h period using a linear-move irrigation system (Figs. 2 and 3). The irrigator was placed directly over each site alternately and was not allowed to move, which resulted in water being applied only to approximately a 10 -m-wide area surrounding each site in the corn field. It is estimated that surface run-off to the lowland site occurred from water applied along an approximately 80 -m-long strip through the middle of the catchment area around the lowland site (approx. an $800-\mathrm{m}^{2}$ area, Fig. 1). Surface run-off was quantified by installing collectors between the corn rows, five at the upland site and six at the lowland site (Fig. 4). Run-off water from the collectors was diverted into buried 1-gallon containers and the water volume was quantified and sampled for chemical analysis (Fig. 3). Median slope of the land surface near the run-off collectors was 0.006 at the upland site and 0.017 at the lowland site.

Movement of water and agricultural chemicals through the unsaturated zone was monitored during the experiment. Water samples were collected from unsaturated-zone samplers and a water table well at each site before, during and after the experiment at approximately 1-h intervals. Suction lysimeters were installed in the unsaturated zone at depths of 
Table 1

Summary of univariate statistics for soil samples from the upper $2 \mathrm{~m}$ at the upland and lowland sites, plus other relevant information

\begin{tabular}{|c|c|c|c|c|c|c|}
\hline Variable (units) & $\begin{array}{l}\text { No. of } \\
\text { samples }\end{array}$ & Mean & $\begin{array}{l}\text { Standard } \\
\text { deviation }\end{array}$ & Median & Minimum & Maximum \\
\hline \multicolumn{7}{|l|}{ (a) Upland sites } \\
\hline Silt and clay content $(\%)$ & 158 & 2.00 & 1.76 & 1.56 & 0.09 & 11.2 \\
\hline$d_{50}$ grain size $(\mathrm{mm})$ & 158 & 0.205 & 0.029 & 0.209 & 0.095 & 0.355 \\
\hline$d_{10}$ grain size $(\mathrm{mm})$ & 177 & 0.098 & 0.019 & 0.098 & 0.023 & 0.173 \\
\hline Bulk density $\left(\mathrm{g} \mathrm{cm}^{-3}\right)$ & 124 & 1.57 & 0.046 & 1.57 & 1.41 & 1.73 \\
\hline Volumetric moisture content & 124 & 0.087 & 0.020 & 0.081 & 0.058 & 0.145 \\
\hline Porosity & 124 & 0.409 & 0.018 & 0.406 & 0.346 & 0.470 \\
\hline Saturation & 124 & 0.213 & 0.055 & 0.195 & 0.136 & 0.392 \\
\hline Organic carbon content & 24 & 0.232 & 0.246 & 0.120 & 0.040 & 0.900 \\
\hline $\begin{array}{l}\text { Saturated hydraulic conductivity } \\
\text { from laboratory analyses }\left(\mathrm{cm} \mathrm{s}^{-1}\right)\end{array}$ & 16 & 0.005 & 0.002 & 0.005 & 0.001 & 0.007 \\
\hline $\begin{array}{l}\text { Depth to water table below land } \\
\text { surface on August } 29,1994(\mathrm{~m})\end{array}$ & n.a. & 4.38 & n.a. & n.a. & n.a. & n.a. \\
\hline $\begin{array}{l}\text { Slope of land surface } 20-45 \mathrm{~m} \\
\text { upgradient of run-off collectors }(\mathrm{m} / \mathrm{m})\end{array}$ & 5 & 0.008 & 0.006 & 0.006 & 0.003 & 0.015 \\
\hline \multicolumn{7}{|l|}{ (b) Lowland site } \\
\hline Silt and clay content $(\%)$ & 141 & 3.77 & 2.85 & 2.67 & 0.19 & 11.5 \\
\hline$d_{50}$ grain size $(\mathrm{mm})$ & 141 & 0.322 & 0.177 & 0.243 & 0.101 & 0.993 \\
\hline$d_{10}$ grain size $(\mathrm{mm})$ & 152 & 0.131 & 0.109 & 0.098 & 0.014 & 0.870 \\
\hline Bulk density $\left(\mathrm{g} \mathrm{cm}^{-3}\right)$ & 98 & 1.56 & 0.054 & 1.57 & 1.28 & 1.74 \\
\hline Volumetric moisture content & 98 & 0.150 & 0.059 & 0.142 & 0.062 & 0.421 \\
\hline Porosity & 98 & 0.412 & 0.021 & 0.409 & 0.342 & 0.517 \\
\hline Saturation & 98 & 0.364 & 0.135 & 0.337 & 0.155 & 0.815 \\
\hline Organic carbon content & 28 & 0.420 & 0.383 & 0.265 & 0.030 & 1.29 \\
\hline \multirow{2}{*}{$\begin{array}{l}\text { Saturated hydraulic conductivity } \\
\text { from laboratory analyses }\left(\mathrm{cm} \mathrm{s}^{-1}\right)\end{array}$} & 11 & 0.008 & 0.006 & 0.005 & 0.002 & 0.022 \\
\hline & & 2.94 & n.a. & n.a. & n.a. & n.a. \\
\hline $\begin{array}{l}\text { Depth to water table below land } \\
\text { surface on August } 29,1994(\mathrm{~m})\end{array}$ & n.a. & 0.015 & 0.006 & 0.018 & 0.008 & 0.023 \\
\hline $\begin{array}{l}\text { Slope of land surface } 20-45 \mathrm{~m} \\
\text { upgradient of run-off collectors }(\mathrm{m} / \mathrm{m})\end{array}$ & 6 & & & & & \\
\hline
\end{tabular}

n.a., not applicable; modified from Delin et al., 2000.

$0.8,1.8,2.6$ and $2.8 \mathrm{~m}$ at the upland site at depths of $0.8,1.8,2.4$ and $2.5 \mathrm{~m}$ at the lowland site (Fig. 4). The suction lysimeters were installed at slightly different depths due to heterogeneities in the soils at each site. The suction lysimeters were constructed of Teflon with a porous ceramic cup. Wick samplers were also installed in the unsaturated zone at depths of 0.8 and $1.5 \mathrm{~m}$ at the upland site, and at the 0.8- and 1.6-m depths at the lowland site. The wick sampler installed at the $0.8-\mathrm{m}$ depth at the lowland site proved to be dysfunctional. The wick samplers were constructed of fiberglass attached to a glass plate, based on the design of Brown et al. (1986). Results from previous field tests indicated that water collected from the wick samplers had larger concentrations and was more representative of mobile soil water that recharged ground water during or soon after a recharge event than soil water from the suction lysimeters (Landon et al., 1999). Soil moisture was measured at each site with two sets of time-domain reflectometry (TDR) probes installed at depths of 0.2 , 0.4, 0.6, 0.8, 1.0, 1.5, 2.0, 2.5 and $3.0 \mathrm{~m}$ (Fig. 4). Water levels were measured continuously in a water table well at each site. Precipitation was measured at each site using a tipping-bucket rain gauge.

Analyses for dissolved major cations and anions were completed by the Geochemistry Laboratory in the Department of Geology and Geophysics at 


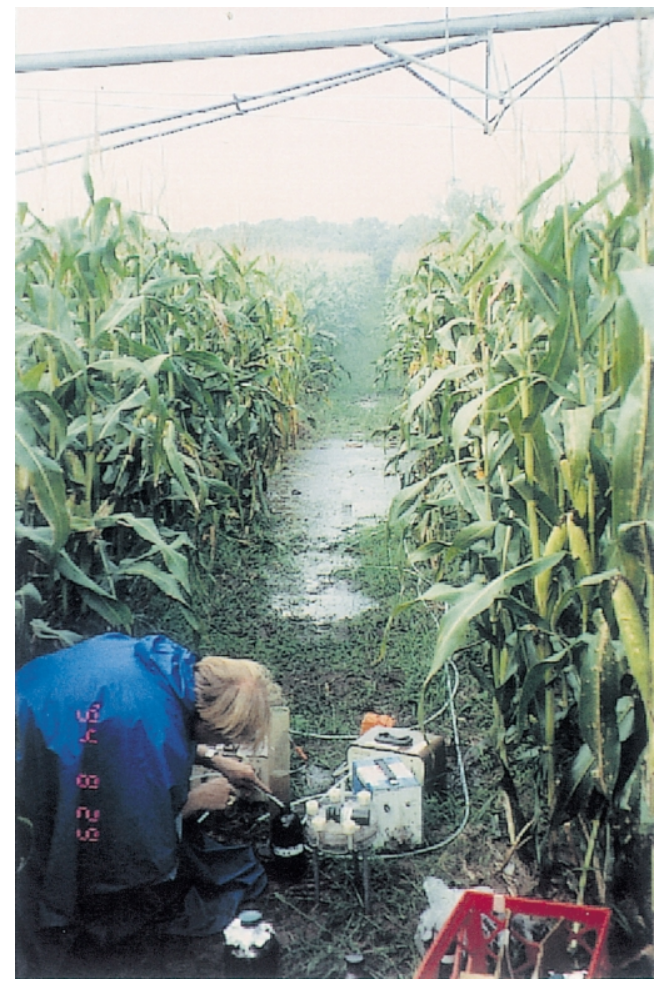

Fig. 3. Sampling run-off water ponded beneath the irrigator due to run-off. The co-author here is collecting water samples from a surface run-off collector at the lowland site. Teflon tubing extends from the collector underneath the irrigator in the background to the pump and filtration unit in the foreground.

the University of Minnesota, Minneapolis; cations were analyzed using inductively-coupled plasmamass spectroscopy and anions were analyzed using ion chromatography. Analyses for atrazine and metabolites de-ethylatrazine and de-isopropylatrazine were completed at a US Geological Survey laboratory in Navarre, Minnesota using gas chromatography/mass spectrometry (Larson et al., 1996). The reporting limits for atrazine, de-ethylatrazine, and de-isopropylatrazine were $0.04,0.06$ and $0.08 \mu \mathrm{g} / 1$, respectively.

Two methods were used to estimate the flux of chemicals to the water table during the experiment: (1) a mass-balance estimate based on concentrations at the water table, herein referred to as the saturated-zone method; and (2) a mass-balance estimate based on unsaturated-zone concentrations, herein referred to as the unsaturated-zone method. Flux estimates based on the saturated-zone method $\left(F_{S}\right)$ were computed using the following equation:

$F_{S}=V \times \Delta C_{w t}$

where $V$ is the volume of water in the upper 0.1 $\mathrm{m}$ of aquifer beneath 1 ha surrounding the site based on a porosity of 0.40 , and $\Delta C_{w t}$ is the change in concentration of a constituent that resulted from the experiment in samples from the water table. Flux estimates based on the unsaturatedzone method $\left(F_{U}\right)$ were computed using the following equation:

$F_{U}=R\left(t_{j}\right) \times C_{u}$

where $R\left(t_{j}\right)$ is the recharge amount based on changes in soil moisture storage in the unsaturated zone, and $C_{u}$ is the average concentration of a given constituent in all unsaturated-zone samplers at each site during the run-off experiment.

The unsaturated-zone recharge $R\left(t_{j}\right)$ for each event was estimated based on a modified version of the zero-flux plane method (Richards 1956). The method is based on the premise that water in the soil above the zero-flux plane moved upward in response to evapotranspiration (ET), and that water below that depth drained downward to the water table as recharge. Integration of changes in soil-moisture content over time for the region between the zero-flux plane and the water table yielded an estimate of recharge $\left[R\left(t_{j}\right)\right]$ as follows:

$R\left(t_{j}\right)=\sum_{i=0}^{X}\left[\theta v_{i}\left(t_{j}\right)-\theta v_{i}\left(t_{j-1}\right)\right] \Delta z_{i}$

where $i$ is an index to the TDR probes equal to zero for the probe nearest the water table increasing upward to a value of $X$ for the probe nearest the zero-flux plane, $\theta v_{i}\left(t_{j}\right)$ is the soil moisture content at sample point $i$ and time $t_{j}$, and $\Delta z_{i}$ is the vertical interval of the unsaturated zone represented by measurements at each TDR probe $i$. The time interval over which recharge was estimated equaled the difference in time between when the maximum soil-moisture storage occurred during the recharge experiment, and the time of minimum soil-moisture storage immediately following the experiment. Delin et al. (2000) provide a detailed description of this method for estimating recharge. 


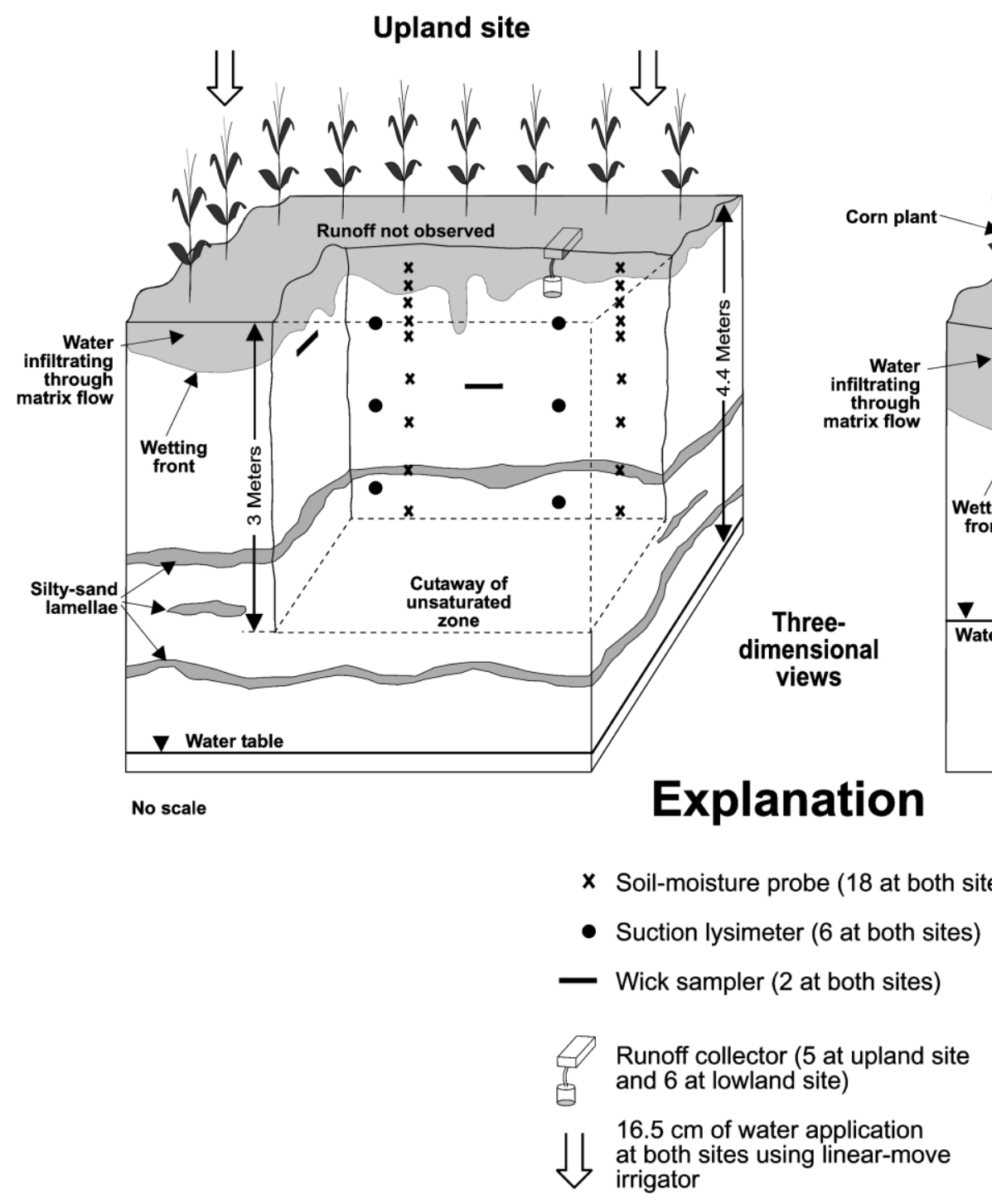

Fig. 4. Three-dimensional conceptual diagram showing unsaturated-zone instrumentation and water flow components at the upland and lowland sites. At any given point in time, the wetting front resulting from the water application was deeper at the lowland site compared to at the upland site. 
Table 2

Mean concentrations of selected agricultural chemicals at the upland and lowland sites during the run-off recharge experiment, August 1994

\begin{tabular}{|c|c|c|c|c|c|c|c|c|}
\hline \multirow{2}{*}{$\begin{array}{l}\text { Sample } \\
\text { location }\end{array}$} & \multicolumn{4}{|c|}{ Upland site } & \multicolumn{4}{|c|}{ Lowland site } \\
\hline & $\begin{array}{l}\text { Chloride } \\
(\mathrm{mg} / \mathrm{l})\end{array}$ & $\begin{array}{l}\text { Nitrate } \\
\text { nitrogen } \\
(\mathrm{mg} / 1)\end{array}$ & $\begin{array}{l}\text { Sulfate } \\
(\mathrm{mg} / 1)\end{array}$ & $\begin{array}{l}\text { Atrazine plus } \\
\text { metabolites }^{\mathrm{a}} \\
(\mu \mathrm{g} / 1)\end{array}$ & $\begin{array}{l}\text { Chloride } \\
(\mathrm{mg} / \mathrm{l})\end{array}$ & $\begin{array}{l}\text { Nitrate } \\
\text { nitrogen } \\
(\mathrm{mg} / 1)\end{array}$ & $\begin{array}{l}\text { Sulfate } \\
(\mathrm{mg} / 1)\end{array}$ & $\begin{array}{l}\text { Atrazine plus } \\
\text { metabolites }^{\mathrm{a}} \\
(\mu \mathrm{g} / 1)\end{array}$ \\
\hline Run-off & - & - & - & - & $3.04(14)$ & $0.24(14)$ & $6.49(14)$ & - \\
\hline $\mathrm{UZ}$ & $5.36(20)$ & $6.20(20)$ & $36.0(20)$ & $7.06(20)$ & $1.69(31)$ & $9.82(31)$ & $23.0(31)$ & $3.06(13)$ \\
\hline WT tab & $5.94(8)$ & $16.9(8)$ & $6.35(8)$ & $139(5)$ & $10.7(11)$ & 30.9 (11) & $9.00(11)$ & $67.3(7)$ \\
\hline
\end{tabular}

${ }^{\text {a }}$ De-ethylatrazine and de-isopropylatrazine.

Number of samples in parentheses; run-off, average of all samples from surface run-off at the site; UZ, average of all samples from unsaturated zone; WT, average of all samples from the water table $(4.2 \mathrm{~m}$ below land surface at the upland site and $2.8 \mathrm{~m}$ below land surface at the lowland site); and -, sample not collected.

The univariate statistics and significance levels were determined with the SAS software package (SAS Institute Inc., 1990). The Kruskal-Wallis rank-sum test was used to evaluate data normality based on a 0.01 significance level.

\section{Results and discussion}

Surface run-off was quantified in five of the six run-off collectors at the lowland site and was not detected in any of the five collectors at the upland site. Run-off water was not available for one of the lowland run-off collectors most likely because the contributing area upslope of this sampler was more than $30 \%$ smaller than for the others. Total run-off volumes in the five run-off collectors varied from 0.25 to $80.2 \mathrm{l}$. The maximum surface run-off rate per unit area was approximately 0.06 $1 / \mathrm{min} / \mathrm{m}^{2}$ with a median of $0.003 \mathrm{l} / \mathrm{min} / \mathrm{m}^{2}$. Based on this median run-off rate, approximately 6001 of water was transported from the approximately $800-\mathrm{m}^{2}$ water application area into the lowland depression (Fig. 1) during the $240 \mathrm{~min}$ that water was applied. If it is assumed that the run-off water infiltrated evenly over the approximately $200-\mathrm{m}^{2}$ lowland depression, this $2.3-\mathrm{m}^{3}$ volume represents approximately $1.2 \mathrm{~cm}$ of additional water that infiltrated at the lowland site due to run-off from the water application area.

The estimated water balances based on soilmoisture measurements support our hypothesis that the difference in recharge between the two sites is approximately equivalent to run-off at the lowland site. Results indicate that $9.5 \mathrm{~cm}$ (or $58 \%$ of the $16.5 \mathrm{~cm}$ of applied water) reached the water table as recharge at the lowland site, whereas $8.0 \mathrm{~cm}$ $(48 \%)$ reached the water table at the upland site. The $1.2 \mathrm{~cm}$ of run-off to the lowland site largely accounts for the $1.5-\mathrm{cm}$ difference in recharge between the two sites. The run-off water represented approximately $7 \%$ of the total applied water and $13 \%$ of the observed recharge at the lowland site.

The concentrations of chloride, nitrate and sulfate in the run-off water were less than concentrations near the water table at the lowland site, indicating that run-off water is not the primary source of the chemicals reaching the water table (Table 2). Concentrations of chloride, nitrate and atrazine plus metabolites were noticeably greater at the water table than in the unsaturated zone (Table 2; Figs. 5 and 6). The cause for this is unclear. Sulfate concentrations at the water table did not follow this pattern, apparently due to greater sorption in the unsaturated zone and subsequent lack of mobilization compared to the other chemicals. Even in sandy soils sulfate is known to be deposited or adsorb to soil organic matter, clay fraction, and iron oxides (Bottcher et al., 1999; Liang et al., 1998).

The concentrations of chloride, sulfate and atrazine plus metabolites were greater in the unsaturated zone at the upland site than at the lowland site based on the Kruskal-Wallis rank sum test ( $P$-values of $0.0398,0.0198$ and 0.0090 , respectively), whereas nitrate concentrations were greater 

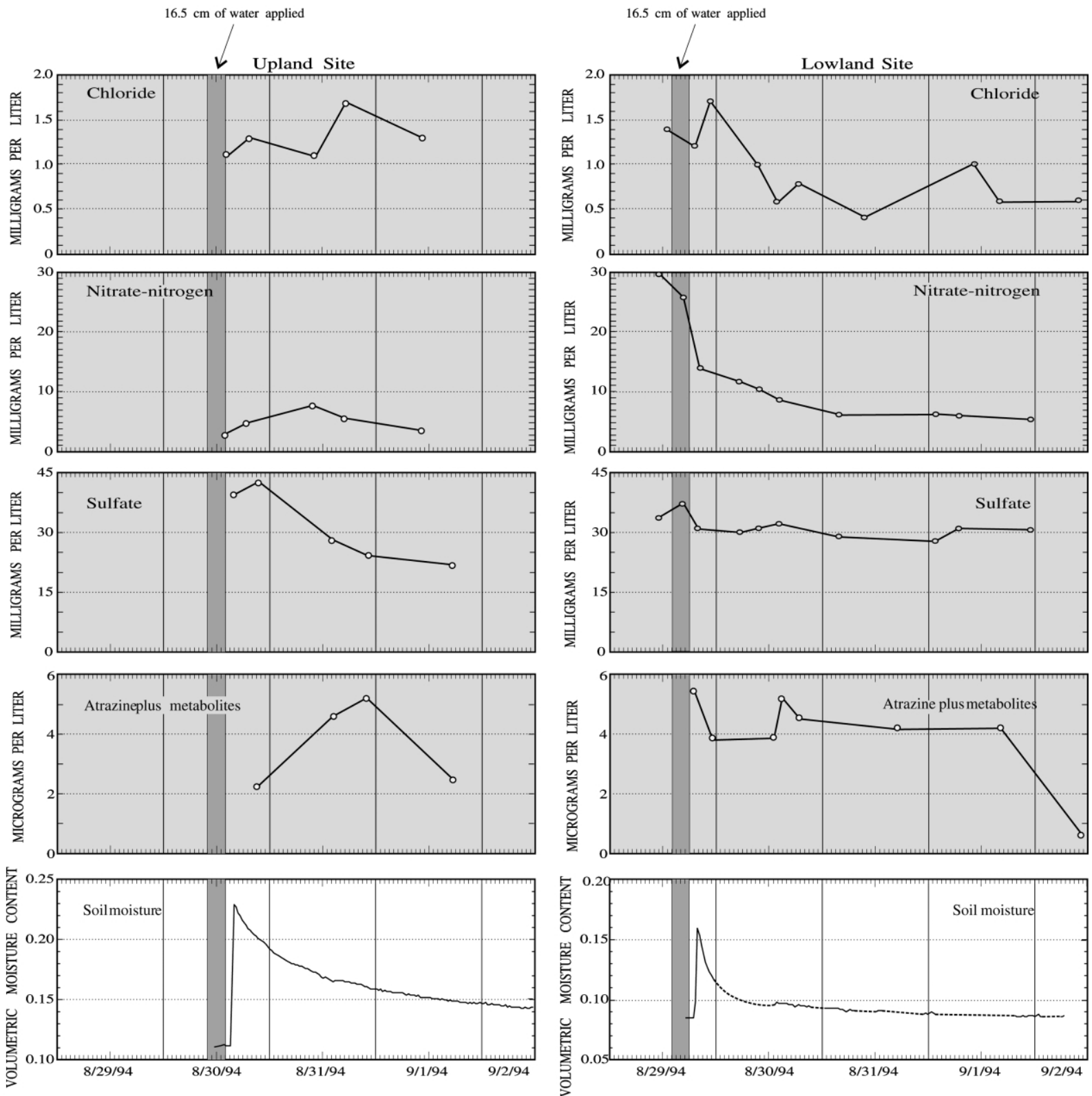

Note: chemical tracers were not applied prior to the st art of this experiment.

Fig. 5. Concentrations of selected agricultural chemicals in samples collected from suction lysimeters at the 1.8-m depth in the unsaturated zone during the run-off recharge experiment, August 29-September 2, 1994. Chemical concentrations at this depth are representative of concentrations throughout the unsaturated zone during the experiment. Changes in soil moisture at the 1.5-m depth during the experiment are shown in the lowermost section of the figure. 

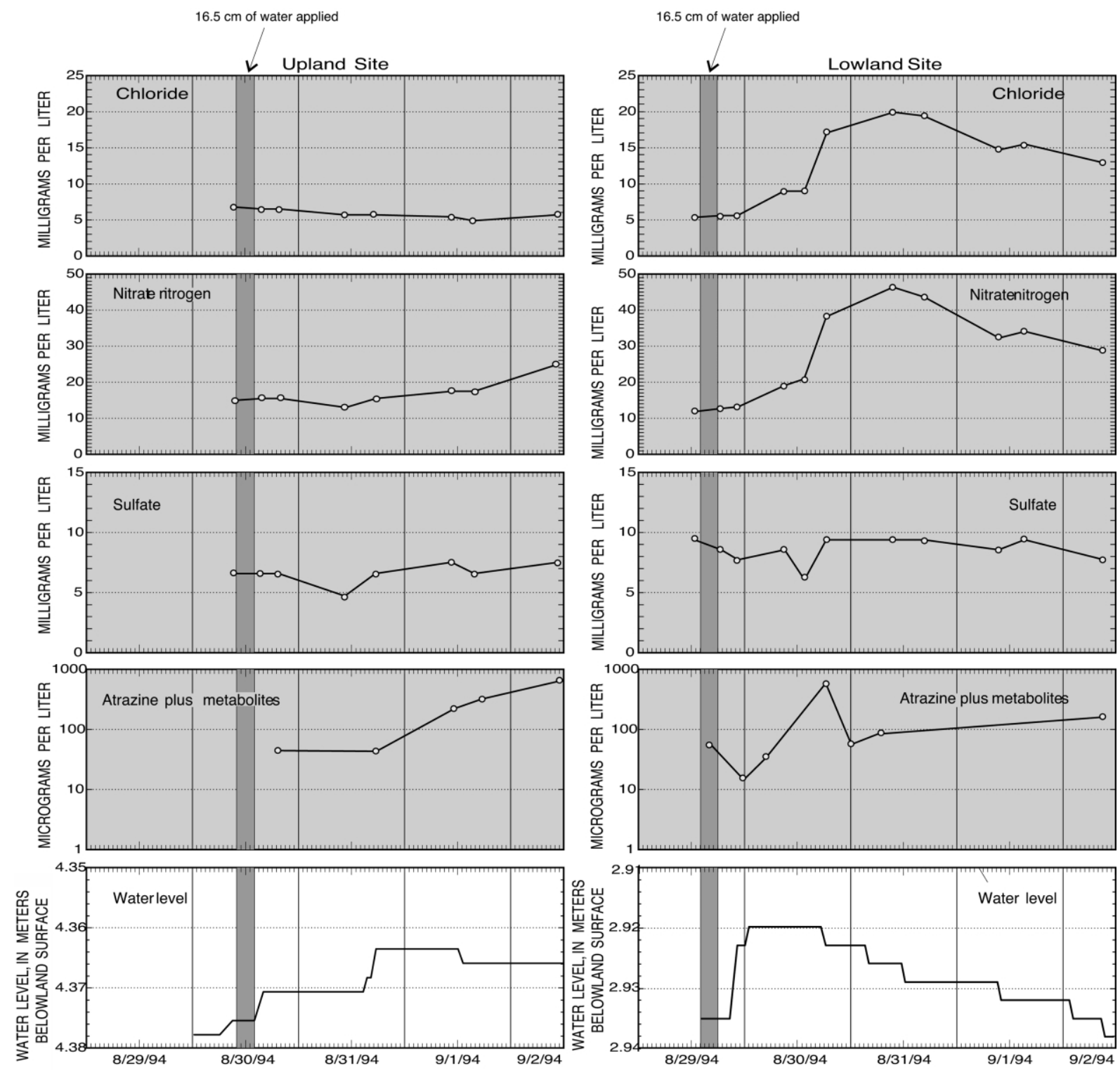

Fig. 6. Concentrations of selected agricultural chemicals at the water table during the run-off recharge experiment, August 29September 2, 1994. Water table fluctuations during the experiment are shown in the lowermost section of the figure.

at the lowland site ( $P$-value of 0.1240$)$ (Table 2). This is likely due to matrix flow, both a combination of dilution of the concentrations at the lowland site from the run-off water and greater sorption of chemicals in the unsaturated zone at the upland site. Chloride and nitrate concentrations increased with depth within the unsaturated zone at both the upland and lowland sites, once again reflecting the effects of flushing and dilution. The increases at the upland site may have been due in part to the presence of thin lamellae (Fig. 4), which are horizontally oriented silty-sand horizons (Delin et al., 2000) that retarded the movement of water and solutes. 
Concentrations of chloride, nitrate and atrazine plus metabolites generally decreased in time within the unsaturated zone at the lowland site during the run-off experiment as shown in Fig. 5. The decreases were likely due to dilution and flushing of the chemicals from the unsaturated zone by the infiltrating run-off water, where concentrations generally were lower (Table 2). Further evidence of this dilution effect can be seen in soil moisture data, which show that the wetting front moved through the entire unsaturated zone at the lowland site within the first $24 \mathrm{~h}$. This rapid movement of the wetting front at the lowland site resulted in the water table rising to a peak approximately $12 \mathrm{~h}$ after the start of the experiment (Fig. 6). At the upland site, concentrations of chloride and nitrate increased slightly and atrazine plus metabolites more than doubled at the $1.8-\mathrm{m}$ depth, peaking approximately 24-36 $\mathrm{h}$ after the experiment began. These increases were most likely the result of flushing of water with greater concentrations from shallower depths in the unsaturated zone. The wetting front at the upland site moved through the unsaturated zone less rapidly than at the lowland site.

The time of transport of chemicals through the unsaturated zone was approximately $30-50 \%$ greater at the upland site than at the lowland site. This is best illustrated in Fig. 6 where peak concentrations at the water table beneath the upland site lagged behind those at the lowland site. A Kruskal-Wallis rank sum test indicated that concentrations of chloride, nitrate and sulfate at the water table were significantly greater at the lowland site than at the upland site ( $P$-values of $0.0398,0.1240$ and 0.0198 , respectively) whereas atrazine plus metabolite concentrations were much greater at the upland site ( $P$-value of 0.0090$)$ (Table 2 and Fig. 6). At the lowland site, the concentrations of chloride at the water table increased by approximately $15 \mathrm{mg} / 1$ within $48 \mathrm{~h}$ after the irrigation water was first applied compared to very little change at the upland site. At the lowland site, the concentrations of nitrate at the water table increased $35 \mathrm{mg} / 1$ within $48 \mathrm{~h}$ after the irrigation water was first applied compared to an increase of only approximately 10 $\mathrm{mg} / 1$ within $66 \mathrm{~h}$ at the upland site. Nitrate concentrations at the upland site were still rising at the end of the experiment, an indication that samples should have been collected for a longer period of time to fully capture the effects of the experiment. Sulfate concentrations changed very little during the experiment at both sites, likely due to sorption within the unsaturated zone. Soil organic matter, as well as the clay fraction and iron oxides in the sandy soil, are known to result in sorption (Bottcher et al., 1999; Liang et al., 1998). Similarly, atrazine plus metabolite concentrations at the water table were greater at the upland site, likely due to less sorption in the unsaturated zone. Atrazine plus metabolite concentrations at the lowland site peaked approximately $32 \mathrm{~h}$ after the irrigation water was first applied, whereas at the upland site concentrations were still rising at the end of the experiment. The increased solute concentrations at the water table during the test likely resulted from mobilization of the chemicals in the soil matrix by the recharge and runoff water moving through the unsaturated zone.

Table 3 shows that the estimated mass fluxes of chloride and nitrate to the water table during the run-off recharge experiment, were greater at the lowland site than at the upland site based on concentrations at the water table. Although sulfate flux estimates were identical for both sites, the estimated flux of atrazine plus metabolites was greater at the upland site than at the lowland site. This increased flux at the upland site likely resulted from the greater sorption and concentration of these chemicals in the unsaturated zone, prior to the experiment, coupled with matrix flow to the water table during the experiment. As mentioned earlier, since the silt, clay and organic carbon contents are greater at the lowland site (Table 1), greater sorption is expected compared to the upland site. Flux estimates based on concentrations at the water table likely are more accurate than estimates based on concentrations in the unsaturated zone, because these data more accurately reflect chemicals that reached the saturated zone 
Table 3

Estimated mass flux of selected agricultural chemicals to the water table during the run-off recharge experiment, August 1994

\begin{tabular}{|c|c|c|c|c|c|c|c|c|}
\hline \multirow[t]{2}{*}{ Method } & \multicolumn{4}{|c|}{ Upland site } & \multicolumn{4}{|c|}{ Lowland site } \\
\hline & Chloride & Nitrate & Sulfate & Atrazine plus & Chloride & Nitrate & Sulfate & Atrazine plus \\
\hline & & nitrogen & & metabolites $^{\mathrm{a}}$ & & nitrogen & & metabolites $^{\mathrm{a}}$ \\
\hline UZ & 4.65 & 5.05 & 29.0 & 0.005 & 1.54 & 8.76 & 21.5 & 0.003 \\
\hline WT & 0.24 & 4.00 & 0.40 & 0.268 & 7.00 & 12.0 & 0.40 & 0.028 \\
\hline Average & 2.45 & 4.53 & 14.7 & 0.137 & 10.5 & 10.4 & 11.0 & 0.016 \\
\hline
\end{tabular}

\footnotetext{
${ }^{a}$ De-ethylatrazine and de-isopropylatrazine.

In $\mathrm{kg} / \mathrm{ha}$; UZ, estimates based on concentrations in the unsaturated zone; and WT, estimates based on concentrations at the water table.
}

whereas concentrations in the unsaturated zone are partially a reflection of sorption.

The flux of chemicals from a single major recharge event such as the one simulated in this run-off experiment can constitute a significant percentage of the overall flux during the entire year. For example, the fluxes of chloride and nitrate at the lowland site based on concentrations at the water table represent 16 and $19 \%$, respectively, of the total annual fluxes in 1994 at the lowland site (unpublished data). At the upland site, corresponding fluxes for these constituents were 1 and 4\%, respectively. The observations of this simulated 100-year rainfall event likely would not hold true for smaller rain events, which may result in concentrations in the run-off water exceeding concentrations in the unsaturated zone.

\section{Summary}

Results of the experiment indicate that run-off of water to the lowland site was the most significant factor affecting differences in the concentrations and fluxes of the agricultural chemicals between the two sites. Run-off of water to the lowland site played a dual role by diluting chemical concentrations in the unsaturated zone as well as increasing the concentrations at the water table, compared to the upland site. Study results illustrate the effects of heterogeneity and complexity of evaluating chemical transport through the unsaturated zone.

Results indicate that matrix flow of water and chemicals was the primary cause for the observed differences between the two sites for this 100-year recurrence interval recharge event. The difference in recharge between the two sites was approximately equivalent to run-off at the lowland site. The concentrations of chloride, nitrate and sulfate in the run-off water were less than concentrations at the water table at the lowland site, indicating that the primary source of the chemicals reaching the water were residuals in the unsaturated zone. Chloride and nitrate concentrations increased with depth within the unsaturated zone at both sites, reflecting the effects of flushing and dilution from matrix flow. The increases at the upland site may also have been due in part to the presence of thin silty-sand lamellae, which retarded the movement of water and solutes resulting in greater sorption within the unsaturated zone. The concentrations of all constituents in the unsaturated zone except nitrate were greater at the upland site, likely due to a combination of dilution of the concentrations at the lowland site from the run-off water and greater sorption of chemicals in the unsaturated zone at the upland site.

Concentrations of chloride, nitrate and atrazine plus metabolites were noticeably greater at the water table than in the unsaturated zone at both sites. Sulfate concentrations at the water table did not follow this pattern, apparently due to greater sorption in the unsaturated zone and subsequent lack of mobilization compared to the other chemicals.

The estimated fluxes of chloride and nitrate to 
the water table during the run-off experiment were greater at the lowland site than at the upland site based on concentrations at the water table. Although sulfate flux estimates were identical for both sites, the estimated flux of atrazine plus metabolites was greater at the upland site than at the lowland site. The flux of chemicals from a single major recharge event, such as the one simulated in this run-off experiment can constitute a significant percentage of the overall flux during the entire year. For example, the fluxes of chloride and nitrate at the lowland site based on concentrations at the water table represented 16 and $19 \%$, respectively, of the total annual fluxes in 1994 at the site.

\section{Acknowledgments}

This research was funded by the US Geological Survey Toxic Substances Hydrology and National Research Programs and was part of the multi-state, multi-agency Management Systems Evaluation Area (MSEA) Program. The MSEA program was a collaborative effort involving the US Department of Agriculture, the US Geological Survey, the US Environmental Protection Agency, and Universities. The authors acknowledge the University of Minnesota Department of Soil, Water, and Climate, the US Department of Agriculture-Agricultural Research Service, and the Minnesota Pollution Control Agency, co-operating agencies for the Minnesota MSEA study. The authors acknowledge two USGS technical reviewers as well as two anonymous reviewers for providing valuable comments that significantly improved the manuscript. Use of trade names in this report is for identification purposes only and does not constitute endorsement by the US Geological Survey.

\section{References}

Bottcher J, Puhlmann M, Springob G. Variability of sulfate sorption in a sandy Gleyic Podzol under a pine stand. Z Pfanzenernahrung Bodenkunde 1999;162(2):113-121.

Brown KW, Thomas JC, Holder MW. Development of a capillary wick unsaturated zone water sampler: co-operative agreement CR812316-01-0. Las Vegas, Nevada: US Environmental Protection Agency, Environmental Monitoring Systems Laboratory, 1986. (105 pp).

Delin GN, Landon MK. Effects of topography on the transport of agricultural chemicals near Princeton, Minnesota, 1992. In: Morganwalp DW, Aronson DA, editors. US Geological Survey Toxic Substances Hydrology Program, Proceedings of the Technical Meeting, September 20-24, 1993. Colorado Springs, (CO, USA): US Geological Survey Water Resources Investigations Report 94-4015, 1996:555-564.

Delin GN, Healy RW, Landon MK, Olsen HW. Spatial variability of unsaturated-zone properties in relation to topography in a sand-plain setting near Princeton, Minnesota, 1992. In: Morganwalp DW, Aronson DA, editors. US Geological Survey Toxic Substances Hydrology Program, Proceedings of the Technical Meeting, September 20-24, 1993. Colorado Springs, (CO, USA): US Geological Survey Water Resources Investigations Report 94-4015, 1996:565-574.

Delin GN, Landon MK, Lamb JA, Anderson JL. Characterization of the hydrogeology and water quality at the Management Systems Evaluation Area near Princeton, Minnesota. U.S. Geological Survey Water Resources Investigations report 94-4149. 1994:54.

Delin GN, Landon MK, Nelson KJ, Wanty RB, Healy RW, Olsen HW, Böhlke JK, Schroyer BR, Capel PD. Hydrogeologic and water-quality data used to evaluate the effects of focused recharge ground-water quality near Princeton, Minnesota, 1991-95. US Geological Survey Open-File report 97-21. 1997:30.

Delin GN, Landon MK, Healy RW, Böhlke JK. Effects of topography and soil properties on recharge at two sites in an agricultural field. J Am Water Resour Assoc 2000;6:1401-1416.

Huff FA, Angel JR. Rainfall frequency atlas of the Midwest. Midwest climate center report 92-03. Illinois state water survey bulletin, vol. 71. 1992. (141 pp).

Landon MK, Delin GN, Lamb JA, Anderson JL, Dowdy RH. Effects of farming systems on ground-water quality at the Management Systems Evaluation Area near Princeton, Minnesota 1991-95: US Geological Survey Water Resources Investigations Report 98-4128. 1998:51.

Landon MK, Delin GN, Komor SC, Regan CP. Comparison of the stable-isotopic composition of soil water collected from suction lysimeters, wick samplers, and cores in a sandy unsaturated zone. J Hydrol 1999;224:45-54.

Larson SJ, Capel PD, Vanderloop AG. Laboratory and quality assurance protocols for the analysis of herbicides in ground water from the Management Systems Evaluation Area, Princeton, Minnesota. US Geological Survey Water Resources Investigations report 95-4178. 1996:18.

Liang JC, Wang MK, King HB. Sulfate sorption of Fu-Shan forest soils. J Chin Agric Chem Soc 1998;36(1):42-56.

Lissey A. Depression-focused transient ground water flow patterns in Manitoba. Geol Assoc Can Spec Pap 1971;9:495-499.

Meyboom P. Unsteady groundwater flow near a willow ring in hummocky moraine. J Hydrol 1966;4:38-62. 
Miller JJ, Acton DF, St. Arnaud RJ. The effect of groundwater on soil formation in a morainal landscape in Saskatchewan. Can J Soil Sci 1985;65:293-307.

Richards LA. Physical conditions of water in soil. In: Black CA, editor. Methods of soil analysis. Madison, Wisconsin: American Society of Agronomy, 1956. p. 128-152.
SAS Institute Inc.. SAS/STAT User's guide. Cary, NC, USA: SAS Institute, 1990. (1686 pp).

US Department of Agriculture. Soil survey, Sherburne County Minnesota, Washington, DC. 1968. 